Marangos, A.M., Groenewegen, P.P., Graaf, N.D. de. Levensfilosofie en zorggebruik in Nederland. Mensen Maatschappij: 2010, 85(2), 135-153

\begin{tabular}{|l|l|}
\hline $\begin{array}{l}\text { Postprint } \\
\text { Version }\end{array}$ & 1.0 \\
\hline Journal website & http://www.mensenmaatschappij.nl/ \\
\hline Pubmed link & \\
\hline DOI & \\
\hline
\end{tabular}

This is a NIVEL certified Post Print, more info at http://www.nivel.eu

\title{
Levensfilosofie en zorggebruik in Nederland
}

\author{
Anna Maria Marangos, Peter P. Groenewegen, NAn DirK De GraAF
}

Anna Maria Marangos is sociologe. Ten tijde van dit onderzoek was ze verbonden aan het NIVEL. Momenteel is ze werkzaam als wetenschappelijk medewerker bij het SCP: a.marangos@scp.nl.

Peter Groenewegen is socioloog. Hij is directeur van het NIVEL - Nederlands instituut voor onderzoek van de gezondheidszorg en bijzonder hoogleraar bij de Capaciteitsgroep Sociologie en het Departement Sociale Geografie Universiteit Utrecht. P.groenewegen@nivel.nl.

Nan Dirk de Graaf is Official Fellow en Professor, Nuffield College, Oxford: nan.degraaf@nuffield.ox.ac.uk.

\section{SUMMARY}

\section{Philosophies of life and Health Care Utilization in the Netherlands}

This study investigates to what extent people's religious denomination relates to health care utilization. Religious denomination is seen as an indicator of a philosophy of life. We distinguish between Christian and Islamic religious and post-modern philosophies of life. Given that modern medical science and ensuing health care interventions are widely accepted, we do not expect a relationship between philosophies of life and the utilization of regular sources of modern health care. However, we do expect differences in areas where more controversy is possible, especially complementary and alternative medicine, but also preventive medicine. As expected, our results show philosophy of life differences in utilization for complementary and alternative medicine.

\section{INLEIDING}

De Nederlandse samenleving van de eerste driekwart van de vorige eeuw was sterk verzuild, deels langs godsdienstige lijnen, en het behoren tot een zuil bepaalde veel keuzes die mensen in het dagelijks leven maakten. De afgelopen decennia zijn West-Europese landen in meerdere of mindere mate geseculariseerd, Nederland in hoge mate (Halman et al., 1999; Beurts, Dekker \& De Hart, 2007; Aarts et al., 2008).

Georganiseerde godsdiensten spelen een minder belangrijke rol in de samenleving en het geloof in een persoonlijke god is vervaagd (De Graaf \& Te Grotenhuis, 2005; 2008). Er zijn aanwijzingen dat religie op een andere, individuelere wijze wordt beleefd; waar mensen niet meer geloven in een persoonlijke god, geloven velen wel in een hogere macht of geest (Dekker \& Stoffels, 2001; Becker \& De Hart, 2006). Het is daarom nog maar de vraag of religie in brede zin, met inbegrip van het geloof in een hogere macht of geest, ook minder invloed heeft op het handelen van Nederlanders. Een andere reden die de vraag naar de invloed van religie op gedrag weer belangrijk maakt, is het toenemende aantal mensen met een islamitische achtergrond in Nederland.

Wij vragen ons daarom in dit onderzoek af in hoeverre religie en een levensfilosofie waarin geloof in een hogere macht een plaats heeft, tegenwoordig van invloed zijn op een specifieke maar belangrijke vorm van handelen, namelijk hulp zoeken bij ziekte. Meer specifiek richten onze vragen zich op het gebruik van alternatieve en preventieve zorg; twee soorten van zorggebruik die meer omstreden zijn dan het gebruik van curatieve zorg van huisarts of specialist. De achterliggende redenering is dat als de invloed van religie zich in de moderne samenleving uit in gedrag, dit op meer omstreden gebieden zal zijn. 
Marangos, A.M., Groenewegen, P.P., Graaf, N.D. de. Levensfilosofie en zorggebruik in Nederland. Mens en Maatschappij: 2010, 85(2), 135-153

Zieken zoeken sinds mensenheugenis hun heil bij natuurgenezers (geneeskundige kruiden, gezondheidsbronnen), in bijgeloof (horoscopen, waarzeggers, geneeskundige stenen), geloof en religieuze praktijken (priesters, heiligen, pelgrimage) en in de reguliere, op wetenschappelijk onderzoek gegrondveste geneeskunde (universitair opgeleide artsen). Vaak wordt een twee- of driesporenbeleid gevolgd waarbij reguliere en alternatieve genezers gelijktijdig worden geraadpleegd (Pescosolido, 1992; Sirois \& PurcStephenson, 2008). Wel wisselt de frequentie van het gebruik van de verschillende geneeswijzen in de loop van de tijd en varieert het gebruik tussen bevolkingsgroepen (Schepers \& Nievaard, 1995). De omstandigheden, de technische en financiële mogelijkheden, en de tradities en gewoonten van de gebruikersgroep spelen daarbij wellicht een rol (Schepers \& Nievaard, 1995; Kabela, 1997).

Tot laat in de negentiende eeuw bestond de westerse geneeskunde nog uit een grote verscheidenheid aan geneeskundige systemen en scholen. Gezondheid was een natuurlijk evenwicht van sappen in het lichaam, en ziekte de verstoring hiervan door potentieel schadelijke invloeden van voeding, leefstijl en omgeving. De biomedische geneeskunde die in de negentiende eeuw opkwam, zocht voor elke ziekte een specifieke, overwegend biologische oorzaak (Schepers \& Nievaard, 1995). Deze ontwikkeling sloot aan bij een moderne levensfilosofie waarin ziekte kan worden genezen door ingrijpen van buitenaf, bijvoorbeeld door middel van chemische of chirurgische ingrepen. De biomedische benadering verkreeg de status van reguliere geneeskunde. De andere, veel oudere opvattingen, benaderingen en geneeskundige systemen kwamen in de marge terecht onder de verzamelnaam 'alternatieve geneeswijzen' (Schepers \& Nievaard, 1995), samen met eerder postmoderne, op heel de mens gerichte benaderingen als de antroposofie.

Empirisch onderzoek naar de relatie tussen de godsdienst die mensen aanhangen en het gebruik van gezondheidszorg is schaars. De laatste grote overzichtsstudie over dit onderwerp is van Schiller en Levin (1988) met een review van dertig studies, waarbij zij concludeerden dat in driekwart van deze studies significante, aan godsdienst gerelateerde, verschillen in zorggebruik tot uitdrukking komen. In hoeverre deze gevonden verschillen verklaarbaar zijn door medische, sociale of demografische factoren bleef onduidelijk. Meer recent buitenlands onderzoek gaat vooral over religieuze opvattingen ten aanzien van specifieke onderwerpen waaronder orgaantransplantatie, transfusies en euthanasie. Het gaat dan vooral om studies bij bepaalde religieuze groeperingen, bijvoorbeeld de Jehova's Getuigen en de Sikh gemeenschap (Sloan \& Bagiella, 2002) of gelovige en niet-gelovige Marokkaanse en Turkse patiënten (De Muynck, 2000). Uit het laatstgenoemde (Belgische) onderzoek bleken sterk gelovige patiënten vaker hun huisarts te consulteren voor preventieve zorg dan niet-gelovigen. Ook bleken gelovigen minder te consulteren voor verslavingsproblemen en voor sociale problemen. Dat is niet verwonderlijk omdat godsdienstige gemeenschappen waarden van matigheid uitdragen en een sociaal netwerk scheppen dat fungeert als vangnet bij sociale problemen. Soortgelijke bevindingen komen voort uit een Amerikaans onderzoek over preventief zorggebruik onder ouderen. De bevindingen daar lieten zowel voor mannen als voor vrouwen een hogere mate van preventief zorggebruik (o.a. griepprik, cholesteroltest, borstkankeronderzoek, baarmoederhalskankeronderzoek en prostaatonderzoek) zien, naarmate mensen zich godsdienstiger voelden (Reindl Benjamins \& Brown, 2004).

In Nederland is er weinig kwantitatief onderzoek naar de samenhang tussen religie en zorggebruik. In het onderzoek 'Nederland Oké', uitgevoerd in 1983 en later bewerkt door Van der Zweep en Knol (1996), is wel een samenhang gevonden tussen religie en algemene waarden en houdingen op het terrein van gezondheid, maar nauwelijks tussen religie en feitelijk gezondheids- en ziektegedrag. In 1980 vroeg Lagendijk (Lagendijk Opinieonderzoek, 1980) in opdracht van de Nederlandse Werkgroep van Praktizijns in de Natuurlijke Geneeskunst ruim duizend respondenten naar hun mening over en ervaring met natuurgeneeskundigen. Veel meer hervormden en gereformeerden bleken zich ooit tot een alternatieve genezer te hebben gewend dan katholieken en niet-gelovigen. Uit de gezondheidsenquête van het CBS blijkt dat het bezoek aan alternatieve genezers de afgelopen decennia is gestegen (CBS statline, 2009). Op individueel niveau heeft kerkbezoek een negatieve samenhang met het oordeel over alternatieve genezers, maar dit is niet van betekenis voor het gebruik. Hoewel het kerkelijk engagement wellicht van grotere betekenis is op het niveau van de opvattingen dan van het gedrag, is er wel een tegenspraak met de eerder genoemde bevinding over hervormden en gereformeerden.

De discussie over de relaties tussen religie, opvattingen en gedrag wordt niet meer alleen gevoerd met betrekking tot de traditionele christelijke godsdiensten. Hoffer deed jarenlang onderzoek naar de praktijk van islamitische geneeswijzen. Islamitische genezers maken onderscheid in natuurlijke en bovennatuurlijke oorzaken van kwalen en aandoeningen (Hoffer, o.a. 1994 en 2000). Volgens Hoffer waren er ten tijde van zijn onderzoek ongeveer honderd praktiserende islamitische genezers in Nederland. Hij schatte dat 
ongeveer 10 procent van de moslimbevolking islamitische genezers consulteerden. De gezondheidsklachten die de patiënten aan hen voorlegden, vloeiden mogelijk voort uit andere klachten die onder andere te maken hadden met hun onzekere sociaal-maatschappelijke positie: onder andere werkloosheid, ontspoorde kinderen en slechte huisvesting (zie ook Hoffer, 2009).

In dit onderzoek proberen we een bijdrage te leveren aan de beantwoording van de vraag naar de invloed van religie op het zorggebruik in een moderne, geseculariseerde samenleving. We toetsen hypothesen die zijn afgeleid uit de gedachtegang dat religies en ideeën over het bestaan van hogere machten een bepaalde levensfilosofie impliceren (zie ook hoofdstuk 7 van Ultee, Arts \& Flap, 2003) met daarbij horende opvattingen over ziekte en zorg. Onze onderzoeksvragen luiden als volgt:

Verschilt het gebruik van alternatieve en preventieve zorg door mensen die zich tot een godsdienstige denominatie rekenen (uitgesplitst naar verschillende godsdienstige groeperingen) van mensen die dat niet doen?

Binnen de categorie mensen die niet in een persoonlijke god geloven of zich tot een religieuze denominatie rekenen, onderscheiden we mensen die in een hogere macht of geest geloven en mensen die dat niet doen. In combinatie met hun opleiding en beroep (hoger opgeleiden in sociale beroepen, conform de indeling van De Graaf en Steyn,1997) hebben we hun levensfilosofie als postmodern bestempeld. We stellen daarbij de vraag:

Verschilt het gebruik van alternatieve en preventieve zorg door mensen met een postmoderne levensfilosofie van mensen die er geen postmoderne levensfilosofie op na houden?

\section{THEORIE EN VOORSPELLINGEN}

Mensen die zich tot een godsdienstige denominatie rekenen, hebben gemeen dat zij zich associëren met de levensfilosofie en het wereldbeeld die kenmerkend zijn voor deze groepering. Wij veronderstellen dat levensfilosofie en wereldbeeld samengaan met opvattingen op belangrijke levensterreinen, waaronder ook ziekte en zorg. Deze opvattingen kunnen al dan niet congruent zijn met het gebruik van bepaalde vormen van zorg (Bishop et al. 2007).

\section{De levensfilosofie van religieuze groeperingen in relatie tot zorggebruik}

In deze paragraaf vergelijken we gedragingen van mensen met traditioneel christelijke en traditioneel islamitische opvattingen met die van mensen die zich niet tot die denominaties rekenen en een postmoderne levensfilosofie met een niet postmoderne levensfilosofie. Per religieuze groepering/levensfilosofie worden voorspellingen gedaan ten aanzien van alternatief en preventief zorggebruik. We veronderstellen daarbij dat opvattingen over ziekte en zorggebruik van mensen die zich tot een van deze groeperingen rekenen congruent zijn met achterliggende uitgangspunten van verschillende vormen van zorggebruik. In zijn algemeenheid is de moderne medische wetenschap en daarop gebaseerde gezondheidszorg wijd geaccepteerd. We verwachten voor reguliere gezondheidszorg dan ook geen of nauwelijks verschillen tussen bevolkingsgroepen naar religieuze achtergrond. We verwachten wel dat mensen die zich rekenen tot een religieuze groepering in hun opvattingen ook ruimte laten voor invloed van een hogere macht en voor meer traditionele, voor-wetenschappelijke geneeswijzen. Verder verwachten we dat een postmoderne levensfilosofie congruent is met alternatieve geneeswijzen (O’Callaghan \& Jordan 2003). Zowel in sommige religieuze groeperingen als binnen groepen mensen met postmoderne opvattingen bestaat (om heel verschillende redenen) weerstand tegen sommige vormen van preventie.

\section{Traditioneel christelijk wereldbeeld en zorggebruik}

In de West-Europese christelijke traditie werd lijden als straf voor de zonden beschouwd. De zieke was eerder een berouwvolle en stervende zondaar dan een patiënt. Hoewel in de afgelopen halve eeuw de invloed van de kerk op de samenleving verminderde, stemden in 1985 nog steeds veel mensen met een streng godsdienstige achtergrond in met uitspraken als 'ziekte is een straf voor zonde', 'gebed is het beste medicijn' en 'lijden heeft zin als je in God gelooft' (SOCON, 1985; in Vellenga, 1992).

Uit onderzoek van het SCP (Kooiker, 1996) over de waardering van gezondheid valt op dat gereformeerden een sterk geloof belangrijker vinden en een goede gezondheid minder belangrijk dan hervormden, katholieken en niet-kerkelijken. Men zou verwachten dat mensen met een traditioneler christelijk wereldbeeld vaker alternatieve genezers raadplegen omdat dit aansluit bij premoderne opvattingen, maar dat is niet in zijn algemeenheid zo. De protestants-christelijke godsdienstethici Van Balen en Jochemsen (1993) stellen dat veel alternatieve geneeswijzen op grond van de bijbel worden 
Marangos, A.M., Groenewegen, P.P., Graaf, N.D. de. Levensfilosofie en zorggebruik in Nederland. Mens en Maatschappij: 2010, 85(2), 135-153

afgewezen, omdat deze geneeswijzen mensen in contact zouden brengen met boze geestelijke machten. Van homeopaten en natuurgenezers lijkt volgens hen weinig kwaad te verwachten.

Met betrekking tot preventie geldt dat een aantal 'strenge' protestantse groeperingen vaccinaties veroordelen (Webbink \& Ultee, 2004). Het streven naar preventie via inenting zou op gespannen voet staan met Gods voorzienigheid en voorbeschikking. Inenting, als poging tot voorkomen, wordt als een uiting van menselijke hoogmoed beschouwd (Douma \& Velema, 1979). Omdat een belangrijke overweging van deze gelovigen is dat de geneeskunde niet van tevoren in de loop van de natuur mag ingrijpen, verwachten we ook een geringere deelname aan preventieve bevolkingsonderzoeken.

De voorspellingen ten aanzien van mensen met een traditionelere christelijk godsdienst in vergelijking met mensen die zich niet tot een godsdienstige groepering rekenen kunnen als volgt worden samengevat. Zij doen:

vaker een beroep op gebedsgenezers of geestelijk verzorgers, homeopaten en natuurgenezers; minder vaak een beroep op andere alternatieve genezers, zoals paranormaal genezers, antroposofisch behandelaars en acupuncturisten;

minder vaak mee aan preventieve bevolkingsonderzoeken (m.b.t. baarmoederhalskanker en borstkanker) en vaccinaties (griepprik).

\section{Traditioneel islamitisch wereldbeeld en zorggebruik}

Dat sommige in Nederland wonende moslims een traditionele islamitische ziekteopvatting hebben, blijkt wel uit het feit dat zij zowel in Nederland als in het land van herkomst zogenaamde 'islamitische genezers' consulteren ( $\underline{\text { Hoffer, 2000). }}$.

In de traditionele geneeskunde van de islamitische wereld zijn profetische geneeskunde en Arabisch/islamitische geneeskunde van belang (Van Dijk, 1993). In de eerste benadering worden ziekten beschouwd als veroorzaakt door magie, het boze oog en boze geesten. Behandelingen bestaan uit het reciteren van de koran, het opzeggen van gebeden en het dragen van amuletten. In de Arabisch/islamitische geneeskunde worden ziekten beschouwd als gevolg van disbalans in het principe van eenheid, tawhid (er is een samenhang tussen al wat geschapen is), en/of disbalans tussen de basiselementen vuur, lucht, water en aarde. Dit komt overeen met de traditionele geneeskunde in Europa. Behandelingen bestaan onder andere uit geneesmiddelen (kruiden), chirurgie en gespreksvoering.

Dijkman en De Haan (1999) beschrijven dat de islam magie, waarzeggerij en toekomstvoorspelling afwijst. Volgens hen wordt de lezer van de koran er voortdurend op gewezen dat er buiten de zichtbare wereld nog een onzichtbare wereld bestaat, maar dat alleen boodschappers van Allah er kennis van nemen en die kennis op juiste wijze overdragen. Gelet op deze visie verwachten we dat moslims vaker dan nietmoslims een beroep doen op islamitische genezers en geestelijk verzorgers, maar niet op andere alternatieve genezers.

Naast bovennatuurlijke oorzaken van ziekten erkennen islamitische genezers ook natuurlijke oorzaken en verwijzen zij voor behandeling van deze natuurlijke oorzaken door naar reguliere medici (Hoffer, 2000).

Ten aanzien van preventieve zorg dient een onderscheid gemaakt te worden tussen vaccinaties en bevolkingsonderzoeken. Er is een minder grote deelname aan baarmoederhalskanker- en borstkankeronderzoek te verwachten door vrouwen met een islamitische achtergrond. In sommige interpretaties zou de koran begrepen kunnen worden als aanmoedigend voor schaamtegevoelens. Zo luidt een uitspraak van de profeet dat schaamte voortkomt uit geloof. In de islam geldt het hele lichaam van de vrouw, met uitzondering van haar gezicht en handen, als schaamstreek (Van der Rhee \& Commers, 1993). Het is voor een moslim verboden om aan een ander dan de echtgenoot de schaamstreek te ontbloten. Het is slechts toegestaan om zich medisch te laten behandelen, indien daartoe de noodzaak bestaat (Van der Rhee \& Commers, 1993). We verwachten dat mensen met islamitische opvattingen preventie niet als noodzaak zien. In 2002 lieten onderzoeksresultaten onder Turken en Marokkanen (dus los van hun godsdienst) voor baarmoederhalskankeronderzoek en borstkankeronderzoek lagere deelnames zien, terwijl er voor griepvaccinaties minder duidelijke verschillen waren (Kulu-Glasgow et al., 2002).

- Samengevat voorspellen we dat mensen met een islamitisch wereldbeeld ten opzichte van mensen uit dezelfde herkomstlanden zonder islamitisch geloof:

- vaker een beroep doen op islamitische genezers en geestelijk verzorgers;

- minder vaak een beroep doen op andere alternatieve genezers;

- even vaak meedoen aan preventieve vaccinaties (griepprik); 
- minder vaak meedoen aan preventieve onderzoeken (m.b.t. baarmoederhalskanker en borstkanker).

\section{Postmodern wereldbeeld en zorggebruik}

De opvattingen over ziekte en zorg die ten grondslag liggen aan alternatieve geneeswijzen, sluiten aan bij

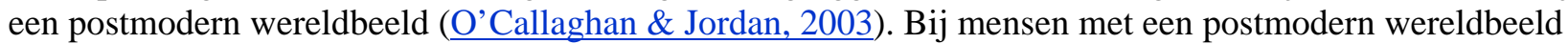
is de moderne levensfilosofie met zijn nadruk op vooruitgangsgeloof, wetenschap als kennisbron bij uitstek en doelrationaliteit onder kritiek komen te staan (Dekker et al., 2001; zie ook Schnabel, 1981). Waar de moderne levensfilosofie nog het meest aansluit bij agnostische of atheïstische opvattingen, zien we bij mensen met een postmoderne levensfilosofie een verschuiving naar een nieuwe godsdienstbeleving. Het gaat bij deze beleving niet zozeer om geloof in een persoonlijke god, maar om geloof in een levenskracht of geest (de term 'ietsisme' is hier recent voor gebruikt, waarbij wel dient te worden vermeld dat recent onderzoek overtuigend laat zien dat door cohortvervanging ook het geloof in 'een' hogere werkelijkheid sterk afneemt (De Graaf \& Te Grotenhuis 2008)). Ten aanzien van de moderne reguliere geneeskunde zou ook een gevoel van onbehagen zijn ontstaan. Het holisme, dat kenmerkend is voor veel alternatieve geneeswijzen, sluit meer aan bij postmoderne opvattingen (Van Dijk, 1993).

Veel alternatieve geneeswijzen gaan uit van een holistisch mensbeeld (Van Dijk, 1993). Ideeën ten aanzien van preventief zorggebruik liggen in de lijn van de afkeer tegen regulier zorggebruik. We verwachten dat mensen met postmoderne opvattingen meer tegen vaccinatie zijn, vanwege de opvatting dat (kinder)ziekten belangrijk zijn in de opbouw van de algemene weerstand van het lichaam, en eveneens bevolkingsonderzoek meer afkeuren, vanwege de opvatting dat het lichaam een zelfhelend vermogen heeft. Zo wordt in een informatiefolder van de Nederlandse Vereniging van Antroposofische Artsen uitgelegd dat het mogelijk is van vaccinatie tegen HPV af te zien zonder een onverantwoord risico te nemen. 'Het risico is mede afhankelijk van de eigen levensstijl en van de manier van omgaan met seksualiteit. (...) We vertrouwen erop dat je zelf verantwoordelijkheid kunt dragen voor je gezondheid en je leven.'

(http://www.nvaa.nl/).

Samenvattend voorspellen wij dat mensen met een postmodern wereldbeeld in vergelijking met mensen zonder postmodern wereldbeeld:

vaker een beroep doen op alternatieve genezers;

minder meedoen aan preventieve zorgprogramma's.

\section{DATA EN MEETINSTRUMENTEN}

\section{Nationale Studie}

Voor de beantwoording van de vraagstelling is gebruikgemaakt van de tweede Nationale Studie naar Ziekten en Verrichtingen in de Huisartspraktijk. Deze studie is uitgevoerd in 104 huisartspraktijken, met een totale praktijkpopulatie van bijna 400.000 ingeschreven personen.

Er is gebruikgemaakt van data die zijn verkregen uit interviews die in 2001 zijn afgenomen bij een aselecte steekproef van alle in de deelnemende huisartspraktijken ingeschreven personen. Er zijn 12.699 interviews gehouden met een respons van 65 procent. De respondenten wijken wat betreft geslacht en leeftijd nauwelijks van de Nederlandse bevolking en wat betreft opleidingsniveau in geringe mate (Schellevis et al., 2003). Omdat willekeurig de helft van de respondenten vragen heeft gekregen over religieuze achtergrond en vanwege de leeftijdselectie (achttien jaar en ouder), bedraagt het aantal bruikbare cases voor de analyses 4563 .

De huisartsen die deelnamen aan de Nationale Studie vormen een goede afspiegeling van de huisartsenpopulatie in Nederland wat betreft leeftijd, geslacht en vestigingsduur. De in de huisartspraktijken ingeschreven patiënten vormen een zeer getrouwe afspiegeling van de Nederlandse bevolking naar leeftijd, geslacht en aard van de ziektekostenverzekering (Schellevis et al., 2003). Slechts 1,5 procent van de steekproef bestaat echter uit moslims, terwijl het percentage moslims in Nederland ten tijde van de dataverzameling 5,3 procent bedroeg (CBS/Statline, 2009). De gemiddelde leeftijd van de moslims in de steekproef is 29 jaar. Vanwege het tekort aan moslims in de steekproef zijn gegevens van 768 Marokkaanse en Turkse allochtonen toegevoegd die zijn verkregen uit de, eveneens in 2001 afgenomen, aparte enquête onder de vier grootste groepen allochtonen. De vragen in deze vragenlijst zijn hetzelfde als die in de Nationale enquête. Allochtonen met geringe kennis van de Nederlandse taal zijn hierbij in hun eigen taal ondervraagd. De respons was 50 procent. Bij vergelijking met de allochtone populatie in Nederland bleken mannen wat betreft leeftijd en geslacht licht oververtegenwoordigd te zijn (Uiters, 2007). 


\section{Variabelen}

Godsdienst is gemeten via de vraag: "Tot welke kerk, religieuze groep of geloofsgemeenschap rekent u zichzelf?” Voor deze studie naar de relatie tussen religie en zorggebruik zijn drie vergelijkingen gemaakt:

1. Drie christelijke groeperingen (rooms-katholieken, hervormden en gereformeerden) versus mensen die zich niet tot een godsdienstige denominatie rekenen. De protestantse groeperingen zijn onderscheiden in 'niet-strenge' en 'strenge'. De midden-orthodoxe richting, de confessionele richting, de vrijzinnige richting, de gereformeerde kerken (synodaal), de Nederlandse hervormde kerken, de overige richtingen Nederlands hervormd en de overige richtingen gereformeerd groepeerden we tot 'niet-strenge' protestantse groepering. De gereformeerde bond, de gereformeerde kerken (artikel 31), de christelijk gereformeerde kerk, de gereformeerde gemeenten en de oud gereformeerde gemeenten vormen de 'strenge' protestanten.

2. Gelovige (islamitische) Turken en Marokkanen versus niet-gelovige Turken en Marokkanen.

3. Mensen met een meer postmodern wereldbeeld versus niet-postmodernen. Postmodernen zijn gedefinieerd als mensen die niet geloven in een persoonlijke god (en zich dus niet tot een van de onderscheiden religieuze denominaties rekenen), maar wel geloven in een of andere levenskracht of geest. Dit laatste is in de enquête gemeten via de vraag: 'Welk van de onderstaande beweringen komt het dichtst bij uw eigen overtuiging? 1 Ik denk eigenlijk niet dat er een of andere geest of god of levenskracht bestaat; 2 ik weet eigenlijk niet wat ik ervan moet denken; 3 er bestaat een soort levenskracht of god; 4 er bestaat een persoonlijke god.' In navolging van Inglehart (1997), De Graaf \& Steijn (1997) en Güveli, Need \& De Graaf (2005), die concluderen dat hoger opgeleide mensen met sociale en culturele beroepen worden gekenmerkt door hun voorkeur voor postmateriële waarden en daardoor meer open staan voor onconventionele opvattingen, definieerden we postmodernen uiteindelijk als hoger opgeleide (hbo/WO) mensen met een sociaal of cultureel beroep, die geloven in een levenskracht of geest.

De beroepen zijn geselecteerd aan de hand van de Standaard beroepenclassificatie 1992 van het CBS, waarbij gecodeerd is conform De Graaf en Steyn, 1997: appendix1. Als vergelijkingsgroep zijn hoger opgeleide mensen geselecteerd die geen sociaal of cultureel beroep hebben en niet geloven in een persoonlijke god, maar ook niet in een levenskracht of geest of niet weten of er een levenskracht of geest is (niet-postmodernen).

In de vergelijking van de drie christelijke groeperingen met mensen die zich niet tot een godsdienstige denominatie rekenen, is gekeken naar regulier zorggebruik (daarvoor verwachten we geen verschillen), bezoek aan alternatieve genezers en gebruik van preventieve zorg. Voor regulier zorggebruik is onderscheid gemaakt in contacten met de huisarts, specialist, paramedicus en psychosociaal hulpverlener. Ten aanzien van huisartsen gaat het om contacten in de afgelopen twee maanden; ten aanzien van de andere reguliere zorg gaat het om contacten in de afgelopen twaalf maanden. Met betrekking tot alternatieve zorg zijn de volgende genezers/behandelaars geselecteerd: acupuncturist, homeopaat, natuurgenezer, paranormaal behandelaar, geestelijk verzorger en islamitische genezer. Voor allen gaat het om contacten in de afgelopen twaalf maanden die betrekking hadden op de gezondheid van de respondent. De variabelen zijn gedichotomiseerd in wel of geen contact gehad. De variabelen die geselecteerd zijn ten aanzien van preventieve zorg betreffen: griepprik gehad in 2000 en/of 2001, griepprik gehad op eigen verzoek, deelname aan bevolkingsonderzoek baarmoederhalskanker in de afgelopen vijf jaar en deelname aan bevolkingsonderzoek borstkanker in de afgelopen 36 maanden.

Voor de vergelijking van Marokkaanse en Turkse moslims en niet-gelovigen en voor de vergelijking van postmodernen en niet-postmodernen is gekeken naar regulier zorggebruik, naar het bezoek aan alternatieve genezers (zonder onderscheid naar aard) en geestelijk verzorgers (dan wel islamitische genezers). Door de veel kleinere aantallen in deze vergelijkingen was het namelijk niet zinvol te onderscheiden naar verschillende soorten alternatieve genezers en gebruik van preventieve zorg.

In alle analyses is gecorrigeerd voor de volgende variabelen die in het algemeen van invloed zijn op zorggebruik (Van der Meer, 1998; Uiters, 2007): leeftijd, geslacht ( 0 = man,1 = vrouw), hoogst voltooide opleiding $(0=$ geen/lager onderwijs, $1=$ middelbaar onderwijs, $2=\mathrm{HBO} / \mathrm{WO})$, ervaren gezondheid $(0=$ (zeer)slecht $/$ matig, 1 = goed, 2 = heel goed $)$, chronische aandoening $(0=$ geen, $1=$ een of meerdere chronische aandoeningen).

\section{Analyse}

Alle analyses zijn uitgevoerd door middel van logistische regressie, waarbij gecorrigeerd is voor de in de vorige paragraaf genoemde achtergrondvariabelen. Ter controle zijn de analyses ook met multiniveauanalyse gedaan vanwege de getrapte steekproeftrekking via de huisartspraktijken. Dat liet geen andere resultaten zien. 
In de tabellen geven we het percentage zorggebruikers in de betreffende groep, zoals berekend is op basis van de logistische regressievergelijking. Ontbrekende waarden zijn paarsgewijs buiten de analyses gelaten. Voor de analyses ten aanzien van preventief zorggebruik zijn de volgende doelgroepen geselecteerd: voor 'griepprik gehad in 2000 en/of 2001' zijn mensen ouder dan 65 jaar geselecteerd, omdat zij ten tijde van het onderzoek in ieder geval tot de oproepcategorie behoorden. Voor 'griepprik gehad op eigen verzoek' zijn de mensen geselecteerd die ooit een griepprik gehad hebben en die de vraag op wiens verzoek men de laatste griepprik had gehad, beantwoord hebben. Voor 'deelname aan baarmoederhalskankeronderzoek' zijn vrouwen tussen 30 en 60 jaar geselecteerd en voor deelname aan 'borstkankeronderzoek' vrouwen tussen 50 en 75 jaar (de oproepcategorieën voor deze bevolkingsonderzoeken). Als gevolg van deze noodzakelijke selecties zijn de aantallen te klein om zinnig te analyseren bij de vergelijking van Marokkaanse en Turkse moslims en niet-gelovigen en bij de vergelijking van postmoderne en nietpostmoderne Nederlanders. Ook hebben we alle typen alternatieve geneeswijzen bij deze groepen samengenomen.

\section{RESULTATEN}

Wat betreft regulier zorggebruik blijkt dat protestanten die behoren tot de niet-strenge groeperingen minder contact hadden met de huisarts dan niet-gelovigen (tabel 1). De verschillen zijn klein: 39,9 procent van de niet-strenge protestanten bezocht de huisarts minimaal één keer in de twee maanden voorafgaande aan het onderzoek tegenover 41,6 procent van de niet-gelovigen. Geen significante verschillen zijn gevonden in het bezoek aan een specialist, paramedicus of psychosociaal hulpverlener. Ondanks het feit dat veel minder mensen alternatieve zorg dan reguliere zorg consulteerden - de percentages van het alternatief zorggebruik betreffen zelfs een of meer bezoeken in het jaar voorafgaande het onderzoek - waren er wel meer en grotere verschillen in het bezoek aan alternatieve genezers. Zowel katholieken (0,9 procent) als niet-strenge protestanten ( 0,4 procent) bezochten minder vaak dan niet-gelovigen (1,9 procent) een acupuncturist. Meer strenge protestanten (5,5 procent) hebben een homeopaat geconsulteerd dan nietgelovigen (2,7 procent). Minder katholieken hebben een natuurgenezer geconsulteerd en meer een paranormaal behandelaar. Alledrie de groepen gelovigen hebben vaker een geestelijk verzorger geraadpleegd dan niet-gelovigen.

\section{[TABLE 1]}

Er zijn geen significante verschillen aangetroffen in het gebruik van preventieve zorg tussen de christelijke groeperingen en niet-gelovigen. Verreweg de meeste 60-plussers (tussen 75 procent en 82,5 procent) kregen in het jaar voorafgaande het onderzoek een griepprik. Opvallend is wel dat weinig strenge protestanten in onze steekproef aangaven op eigen verzoek een griepprik te hebben gehad. Het aandeel mensen uit de oproepcategorieën dat meedeed aan de bevolkingsonderzoeken naar baarmoederhalskanker en borstkanker is vergelijkbaar met dat van de griepprik: tussen 75 procent en 83 procent van de vrouwen tussen 30 en 60 jaar gaven gehoor aan de oproep voor het vijfjaarlijkse baarmoederhalskankeronderzoek en tussen 81 procent en 84,2 procent vrouwen tussen 50 en 75 jaar deden dat voor de driejaarlijkse oproep voor borstkankeronderzoek.

In het zorggebruik van Marokkaanse en Turkse moslims is slechts één verschil significant in vergelijking met Marokkaanse en Turkse niet-gelovigen (tabel 2). Dat is het lagere percentage Turkse moslims (44,8\%) dat contact had met een medisch specialist in vergelijking met het percentage van Turkse niet-gelovigen $(57,4 \%)$. Het bezoek aan islamitische genezers is wel lager onder beide niet-gelovige groepen, maar de verschillen zijn niet significant. Hier spelen de kleine aantallen in deze analyse een rol.

Met betrekking tot regulier zorggebruik zijn geen significante verschillen geconstateerd tussen postmodernen en niet-postmodernen, ondanks dat het er in tabel 3 op lijkt dat meer postmodernen (29,5 procent) paramedici bezochten dan niet-postmodernen (18 procent). Significant meer postmodernen dan niet-postmodernen consulteerden een alternatieve genezer: 21,6 procent versus 9 procent. Het is helaas niet mogelijk om aan te geven in welk soort alternatieve zorg de grootste verschillen bestaan. Vanwege de kleine aantallen was het in deze analyse namelijk niet mogelijk om een uitsplitsing te maken naar verschillende alternatieve zorgaanbieders. 
Marangos, A.M., Groenewegen, P.P., Graaf, N.D. de. Levensfilosofie en zorggebruik in Nederland. Mensen Maatschappij: 2010, 85(2), 135-153

\section{[TABEL 2] AND [TABEL 3]}

\section{CONCLUSIE EN DISCUSSIE}

\section{Theoretische aspecten}

De resultaten van dit onderzoek maken duidelijk dat levensfilosofie en religie slechts zeer ten dele van belang zijn voor zorggebruik. De gevonden verschillen hebben vooral betrekking op het gebruik van een meer controversiële vorm van zorg, namelijk alternatieve geneeswijzen. Daar zien we enkele significante verschillen tussen mensen die zich tot een van de traditionele christelijke denominaties rekenen en mensen die zich niet tot een kerkgenootschap rekenen. Ook mensen met een postmoderne levensfilosofie hadden vaker contact met alternatieve genezers.

Zoals verwacht lijken voor reguliere zorgvoorzieningen verschillen in levensfilosofie en wereldbeeld in het algemeen niet te leiden tot verschillen in gebruik. Niet-strenge protestanten bleken wel iets minder vaak naar de huisarts te gaan en Turkse moslims bezochten minder vaak een specialist. Voor deze onverwachte verschillen hebben wij geen verklaring. Voor preventieve zorg is alleen een vergelijking gemaakt tussen de grote christelijke groeperingen en niet-gelovigen en daar zijn geen verschillen gevonden.

Klaarblijkelijk heeft het al dan niet lid zijn van een islamitische groepering nauwelijks invloed op zorggebruik in Nederland. Ook mensen met een christelijk wereldbeeld verschilden nauwelijks van mensen met een niet christelijk wereldbeeld ten aanzien van regulier zorggebruik en preventie. Dat streng protestanten een voorkeur hebben voor homeopaten komt overeen met eerder onderzoek (Van Dijk, 1993). Het hogere gebruik van paranormale genezers onder katholieken zou verband kunnen houden met het traditionele geloof in wonderen. De symboliek die een medium als Jomanda uitstraalde, sloot aan bij katholieke symboliek (Knibbe \& Westra, 2003). Hoewel de aantallen hier wellicht te klein zijn om uitspraken te doen, lijkt het er op dat niet hetzelfde geldt voor bezoek aan natuurgenezers. Staan natuurgenezers niet even dicht bij de natuur, en dus bij de schepping, als homeopaten? Mogelijke redenen kunnen zijn dat natuurgenezers zich niet zo profileren op de gezondheidsmarkt als homeopaten en wellicht behoren consulten en medicijnen van natuurgenezers niet tot het (aanvullende) vergoedingenpakket van zorgverzekeraars. Voor homeopathie is dat laatste vaak wel het geval.

Een andere bevinding heeft betrekking op het preventieve zorggebruik van mensen met een traditioneel christelijk wereldbeeld en roept vragen op. In tegenstelling tot de verwachting maakten zij hier namelijk net zoveel gebruik van als mensen zonder traditioneel christelijk wereldbeeld. Zij haalden niet minder vaak een griepprik, maar slechts weinig strenge protestanten gaven aan ooit op eigen verzoek een griepprik te hebben gehad. Is het echt zo dat strenge protestanten zelf niet om een griepprik vroegen of wilden ze niet toegeven om deze prik gevraagd te hebben? Het is ten aanzien van preventief gedrag de vraag of vroege opsporing van ziekte als hetzelfde wordt gezien als het voorkomen van ziekte door vaccinaties. In onderzoek in andere landen en culturen is zelfs een positieve relatie tussen godsdienstigheid en het gebruik van preventieve zorg gevonden (De Muynck, 2000; Reindl Benjamins \& Brown, 2004). Een pragmatisch punt is dat in bevolkingssteekproeven waarschijnlijk relatief weinig 'strenge' protestanten worden aangetroffen die vaccinatie principieel afwijzen.

\section{Methodologische problemen}

Onderhavig onderzoek kenmerkt zich doordat op een systematische en indirecte wijze geprobeerd is om verschillen in het gedrag van mensen die zich al dan niet tot een godsdienstige denominatie rekenen en het gedrag van mensen met een postmoderne en een niet-postmoderne levensfilosofie te voorspellen en te toetsen. De gebruikte methode, een grootschalige landelijke enquête, maakte het mogelijk om kwantitatieve analyses te verrichten. Toch bleken de aantallen soms te klein voor het vergelijken van subgroepen (zoals gelovige en niet-gelovige Turken en Marokkanen) in combinatie met relatief zeldzame gebeurtenissen. In de vorige paragraaf werd duidelijk dat verschillen in zorggebruik slechts gedeeltelijk werden verklaard door verschillen in wereldbeeld, zoals geïndiceerd door godsdienstige denominatie dan wel geloof in een of andere levenskracht gecombineerd met beroep. In de enquête zijn geen vragen gesteld om te exploreren hoe mensen denken over ziekte, genezing en de rol van religie daarin. Ook eventuele 'religieuze' verschillen tussen het werk van natuurgenezers en homeopaten en tussen paranormale genezers en geestelijk verzorgers zouden kunnen worden opgehelderd. Tevens zou de meting van 'gelovigheid' verbeterd kunnen worden als ook naar andere indicatoren wordt gekeken, bijvoorbeeld naar de mate van kerkbezoek, frequentie van bidden en naar hoe belangrijk God of Allah is in het leven van de respondent. Verder zou de meting van 
Marangos, A.M., Groenewegen, P.P., Graaf, N.D. de. Levensfilosofie en zorggebruik in Nederland. Mens en Maatschappij: 2010, 85(2), 135-153

postmoderne levensfilosofie verbeterd kunnen worden, waardoor het in de operationalisatie niet nodig is om gebruik te maken van empirische relaties met opleiding en beroep.

Een beperking van onderhavig onderzoek is dat alleen gekeken is naar het aantal personen dat van bepaalde zorg gebruikgemaakt heeft. Dat is gedaan, omdat niet in alle vragenlijsten is gevraagd naar het aantal bezoeken aan de zorgverlener. Nauwkeuriger metingen kunnen worden gedaan indien er eveneens wordt gekeken naar de frequentie van het zorggebruik. Een andere aanvulling betreft onderzoek naar patronen van zorggebruik in plaats van het gebruik van afzonderlijke zorgsoorten (Pescosolido, 1992), zodat het twee- of driesporenbeleid dat mensen volgen (bijvoorbeeld zowel naar de huisarts als naar de alternatieve genezer gaan) bij de analyses kan worden betrokken. Onderscheid in het gebruik van uitsluitend reguliere zorg, uitsluitend alternatieve zorg, dan wel een combinatie van beide kan inzicht geven in het taboekarakter dat in bepaalde groepen zou kunnen bestaan rond een van beide benaderingen van gezondheid.

Tegen de achtergrond van secularisatie en veranderingen van religieuze beleving in Nederland is het begrijpelijk dat godsdienstige denominatie steeds minder vaak als 'standaard' achtergrondkenmerk in sociologisch onderzoek wordt meegenomen. Tegelijkertijd is het belangrijk om onderzoek te doen naar de invloed van individuelere beleving van religie op het gedrag, vooral in meer omstreden situaties.

\section{LITERATUUR}

Aarts, O, Need, M. te Grotenhuis \& N.D. De Graaf (2008) 'Does Belonging Accompany Believing? Correlations and Trends in Western Europe and North America between 1981 and 2000.' Review of Religious Research, 50: 16-34.

Balen, E.C. van \& Jochemsen, H. (1993). Mag ik alternatief behandeld worden? Dienst der genezing, 22 (2), 45-52.

Becker, J.W. \& Hart, J. De (2006). Godsdienstige veranderingen in Nederland. Verschuivingen in de binding met de kerken en de christelijke traditie. Den Haag: SCP.

Bishop, F.L., Yardley L. \& Lewith, G.T. (2007). A systematic review of beliefs involved in the use of complementary and alternative medicine. J Health Psychol,12(6), 851-67.

Cassee, E.T. (1973). Naar de dokter: enkele achtergronden van ziektegedrag en gezondheidszorg. Leiden: TNO.

Dekker, G. \& Stoffels, H.C. (2001). Godsdienst en samenleving; een introductie in de godsdienstsociologie. Kampen: Kok.

Douma, J. \& Velema, W.H. (1993). Polio: afwachten of afweren. Amsterdam: Bolland.

Dijk, P. van (1993). Geneeswijzen in Nederland: compendium voor alternatieve geneeswijzen. Deventer: Ankh-Hermes bv.

Dijkman, P. \& Haan, M. de (1999). Cultureel bepaalde ziektebeleving en geneeswijzen. Huisarts en Wetenschap, 42 (5), 205-10.

Furer, J.W. (2001). Protoprofessionalisering: een empirisch onderzoek naar de validiteit van protoprofessionalisering en naar haar verbanden met gezond(heids)gedrag, ziektegedrag en gezondheidstoestand. Katholieke Universiteit Nijmegen, proefschrift.

Graaf, N.D. de \& Steijn, B. (1997). De 'service' klasse in Nederland: een voorstel tot aanpassing van de EGP-klassenindeling. Tijdschrift voor Sociologie, 18 (1-2), 131-54.

Graaf, N.D. de \& M. te Grotenhuis (2005) Afnemend geloof in God en toenemend geloof in een hogere werkelijkheid? Mens \& Maatschappij, 80: 143-158.

Graaf, N.D. \& M. te Grotenhuis (2008) Traditional Christian Belief and Belief in the Supernatural: Diverging Trends in the Netherlands Between 1979 and 2005? Journal for the Scientific Study of Religion. 47: 585598.

Güveli, A., A. Need \& N.D. de Graaf (2005) De opkomst van de 'nieuwe'sociale klassen binnen de dienstenklasse in Nederland: politieke oriëntatie van de 'nieuwe'klassen tussen 1970 en 2000. Mens \& Maatschappij, 80: 257-279.

Halman, L., Pettersson, T. \& Verweij, J. (1991). The religious factor in contemporary society: the differential impact of religion on the private and public sphere in comparative perspective. International Journal of Comparative Sociology, 141-160.

Hoffer, C. (1994). Islamitische genezers en hun patiënten: gezondheidszorg, religie en zingeving. Amsterdam: Het Spinhuis.

Hoffer, C. (2000). Volksgeloof en religieuze geneeswijzen onder moslims in Nederland. Amsterdam: Thela Thesis. 
Marangos, A.M., Groenewegen, P.P., Graaf, N.D. de. Levensfilosofie en zorggebruik in Nederland. Mensen Maatschappij: 2010, 85(2), 135-153

Hoffer, C. (2009). Psychische ziekten en problemen onder allochtone Nederlanders: beleving en hulpzoekgedrag. Assen: Van Gorcum.

Inglehart, R. (1997). Modernization and postmodernization: cultural, economic and political change in 43 societies. New Jersey: Princeton University Press.

Kabela, M. (1997). Reguliere therapieën en islamitische geneeswijzen. Medisch Contact, 22, 693-694.

Knibbe K. \& Westra I. (2003). Van ongeloof naar zeker weten: betekenisgeving en legitimatie in de context van het fenomeen Jomanda. Sociale Wetenschappen, 46, 75-92.

Kulu-Glasgow, I., Bakker, D., Weide, M., Tacken, M. \& Tiersma W. (2002). Influenza-vaccinatie onder allochtone en autochtone ouderen: aanpak en bereik. Tijdschrift voor Sociale Gezondheidszorg, 80 (8), 508-13.

Lagendijk Opinieonderzoek (1980). Meningen over en ervaringen met de natuurgeneeskundige. Hilversum: NWP.

Meer, J.W.D. van der (1998) Equal care, equal cure? Socioeconomic differences in the use of health services and the course of health problems. Proefschrift Erasmus Universiteit.

Muynck, A. de (2000). Religie, zorgvraag en gezondheidsgedrag. Huisarts Nu, 4, 175-181.

O'Callaghan, F.V., N. Jordan (2003). Postmodern values, attitudes and the use of complementary medicine. Complementary Therapies in Medicine, 11, 28-32.

Pescosolido, B.A. (1992). How people seek help. American Journal of Sociology, 94 (4), 1096-1138.

Reindl Benjamins, M. \& Brown, C. (2004). Religion and preventive health care utilization among the elderly. Social Science \& Medicine, 58, 109-118.

Rhee, L. van der \& Commers, M. (2003). De islamitische visie op gezondheid en ziekte. Huisarts in Nederland, 1, 20-24.

Schellevis, F.G., G.P. Westert, D.H. de Bakker, P.P. Groenewegen, J. van der Zee, and J.M. Bensing. De tweede Nationale Studie naar ziekten en verrichtingen in de huisartspraktijk: aanleiding en methoden. Huisarts \& Wetenschap 46:7-12, 2003.

Schepers, R.M.J. \& Nievaard, A.C. (1995). Ziekte en Zorg, inleiding in de medische sociologie. Houten: Stenfert Kroese.

Schiller, P.L. \& Levin, J.S. (1988). Is there a religious factor in health care utilisation? A review. Social Science of Medicine, 27 (12), 1369-1379.

Schnabel, P (1982). Tussen stigma en charisma; nieuwe religieuze bewegingen en geestelijke volksgezondheid, Deventer: Van Lochum Slaterus.

Sirois, F.M. \& Purc-Stephenson, R.J. (2008). Alternative medicine: consumer decision factors for initial and long-term use of complementary and alternative medicine. Complementary Health Practice Review 13; 320.

Sloan, R.P. \& Bagiella, E. (2002). Claims about religious involvement and health outcomes. The Society of Behavioral Medicine, 24 (1), 14-21.

Uiters, E. (2007). Primary health care use among ethnic minorities in the Netherlands, Utrecht: NIVEL (dissertation Erasmus University Rotterdam).

Ultee, W., Arts, W. \& Flap, H. (2003). Sociologie: vragen, uitspraken, bevindingen. Groningen: Martinus Nijhoff.

Vellenga, S.J. (1992). Zin, ziel en zorg: over levensbeschouwing en geestelijke gezondheidszorg. Kampen: Kok.

Webbink, E. \& Ultee, W. (2004). Van polio tot meningokokken-C: gedragingen en opvattingen van bevindelijke gereformeerden in Nederland. Mens \& Maatschappij, 79: 4-23.

Zweep, A. van der \& Knol, H. (1996). Gezondheid, een baken voor het leven? De samenhang tussen waarden, attitudes en gedrag met betrekking tot gezondheid. In Kooiker, S.E. \& Mootz, M. (red.), Patiënt en professie. Rijswijk: SCP. 
Marangos, A.M., Groenewegen, P.P., Graaf, N.D. de. Levensfilosofie en zorggebruik in Nederland. Mens en Maatschappij: 2010, 85(2), 135-153

\section{TABELLEN}

Tabel 1 Gebruik van reguliere, alternatieve en preventieve zorg door autochtone respondenten (in percentages welke berekend zijn op basis van logistische regressie analyse, waarbij gecorrigeerd is voor leeftijd, sekse, opleiding, ervaren gezondheid en chronische aandoeningen)

\begin{tabular}{|c|c|c|c|c|c|}
\hline & & $\begin{array}{l}\text { Katholiek } \\
\text { N1 = } 1305\end{array}$ & $\begin{array}{l}\text { Protestant } \\
\text { niet streng } \\
\mathrm{N} 1=561\end{array}$ & $\begin{array}{l}\text { Protestant } \\
\text { streng } \\
\text { N1 = } 164\end{array}$ & $\begin{array}{l}\text { Niet- } \\
\text { gelovig } \\
\text { N1 = } 2533\end{array}$ \\
\hline Regulier & Huisarts $^{2}$ & 42,3 & $39,9^{\star}$ & 41,5 & 41,6 \\
\hline Specialist ${ }^{2}$ & 21,5 & 22,5 & 20,7 & 18,8 & \\
\hline Paramedicus $^{3}$ & 23,6 & 20,3 & 23,2 & 24,4 & \\
\hline Psychosociaal hulpverlener ${ }^{3}$ & 4,6 & 3,6 & 6,1 & 6,5 & \\
\hline Alternatief & Acupuncturist $^{3}$ & $0,9^{*}$ & $0,4^{*}$ & 1,2 & 1,9 \\
\hline Homeopaat $^{3}$ & 2,4 & 1,8 & $5,5^{*}$ & 2,7 & \\
\hline Natuurgenezer ${ }^{3}$ & $0,4^{*}$ & 0,9 & 0,6 & 1,3 & \\
\hline Paranormaal behandelaar ${ }^{3}$ & $2,5^{\star}$ & 0,7 & 0,6 & 1,8 & \\
\hline Manueel therapeut ${ }^{3}$ & 4,4 & 5,0 & 2,4 & 4,7 & \\
\hline Geestelijk verzorger $^{3}$ & $1,5^{\star}$ & $3,7^{\star}$ & $11,6^{\star}$ & 0,1 & \\
\hline Overig alternatief ${ }^{3}$ & 1,7 & 1,8 & 1,8 & 2,2 & \\
\hline Preventief & $\begin{array}{l}\text { Griepprik in } 2000 \\
\text { en/of } 2001\end{array}$ & 79,9 & 82,4 & 75,0 & 82,5 \\
\hline Griepprik op eigen verzoek & 8,0 & 7,9 & 2,0 & 8,8 & \\
\hline $\begin{array}{l}\text { Onderzoek } \\
\text { baarmoederhalskanker }\end{array}$ & 83,0 & 80,9 & 75,0 & 79,5 & \\
\hline Onderzoek borstkanker & 84,2 & 81,0 & 82,9 & 83,1 & \\
\hline
\end{tabular}

* Statistisch significant verschil met de referentiegroep niet-gelovigen $(p<0.05)$

${ }^{1} \mathrm{~N}$ is lager bij preventieve zorgvoorzieningen: griepprik, griepprik op eigen verzoek, onderzoek baarmoederhalskanker en onderzoek borstkanker

${ }^{2}$ Eén of meer bezoeken in de afgelopen twee maanden

${ }^{3}$ Eén of meer bezoeken in het afgelopen jaar 
Marangos, A.M., Groenewegen, P.P., Graaf, N.D. de. Levensfilosofie en zorggebruik in Nederland. Mens'en Maatschappij: 2010, 85(2), 135-153

Tabel 2 Gebruik van reguliere en alternatieve zorg door Turkse en Marokkaanse respondenten (in percentages welke berekend zijn op basis van logistische regressie analyse, waarbij gecorrigeerd is voor leeftijd, sekse, opleiding, ervaren gezondheid en chronische aandoeningen)

\begin{tabular}{llllll}
\hline & & $\begin{array}{l}\text { Marokkaans } \\
\text { moslim } \\
N=311\end{array}$ & $\begin{array}{l}\text { Marokkaans } \\
\text { niet-gelovig } \\
N=58\end{array}$ & $\begin{array}{l}\text { Turks } \\
\text { moslim } \\
N=297\end{array}$ & $\begin{array}{l}\text { Turks } \\
\text { niet-gelovig } \\
N=101\end{array}$ \\
\hline \multirow{2}{*}{ Regulier } & Huisarts1 & 48,6 & 41,4 & 53,0 & 51,5 \\
& Specialist2 & 40,8 & 34,5 & $44,8^{*}$ & 57,4 \\
& Paramedicus2 & 16,4 & 17,2 & 16,2 & 15,8 \\
& Psychosociaal hulpverlener2 & 9,0 & 8,6 & 9,4 & 9,9 \\
& Alternatieve genezer2 & 1,6 & 0,0 & 2,0 & 5,0 \\
& Geestelijk verzorger of & 2,9 & 0,0 & 4,7 & 1,0 \\
& islamitische genezer2 & & & & \\
\hline
\end{tabular}

* statistisch significant verschil met de referentiegroep Turks niet-gelovigen $(p<0.05)$

1 Één of meer bezoeken in de afgelopen twee maanden

2 Één of meer bezoeken in het afgelopen jaar 
Marangos, A.M., Groenewegen, P.P., Graaf, N.D. de. Levensfilosofie en zorggebruik in Nederland. Mens en Maatschappij: 2010, 85(2), 135-153

Tabel 3 Gebruik van reguliere en alternatieve en zorg door hoger opgeleide respondenten (in percentages welke berekend zijn op basis van logistische regressie analyse, waarbij gecorrigeerd is voor leeftijd, sekse, opleiding, ervaren gezondheid en chronische aandoeningen)

\begin{tabular}{llll}
\hline & & Postmodern & Niet-postmodern \\
& & $\mathbf{N}=\mathbf{1 3 9}$ & $\mathbf{N}=\mathbf{2 4 6}$ \\
\hline \multirow{2}{*}{ Regulier } & Huisarts1 & 35,3 & 31,4 \\
& Specialist1 & 21,6 & 14,3 \\
& Paramedicus2 & 29,5 & 18,0 \\
& Psychosociaal hulpverlener2 & 10,1 & 7,3 \\
& Alternatief & $21,6^{*}$ & 9,0 \\
& Geestelijk verzorger2 & 2,1 & 0,0 \\
\hline
\end{tabular}

* statistisch significant verschil met de referentiegroep niet-postmodernen $(p<0.05)$

1 Één of meer bezoeken in de afgelopen twee maanden

2 Één of meer bezoeken in het afgelopen jaar 